\section{Vase Life of New Cut Flower Cultivars}

\author{
Erin M.R. Clark ${ }^{1}$, John M. Dole ${ }^{2,4}$, Alicain S. Carlson ${ }^{1}$, \\ Erin P. Moody ${ }^{1}$, Ingram F. McCall ${ }^{3}$, Frankie L. Fanelli ${ }^{1}$, \\ and William C. Fonteno ${ }^{2}$
}

ADDITIONAL INDEX WORDs. hydrator, preservative

SumMARY. Each year a wide variety of new cultivars and species are evaluated in the National Cut Flower Trial Programs administered by North Carolina State University and the Association of Specialty Cut Flower Growers. Stems of promising and productive cultivars from the National Trial Program were pretreated with either a commercial hydrating solution or deionized (DI) water and placed in either a commercial holding solution or DI water. Over 8 years, the vase life of 121 cultivars representing 47 cut flower genera was determined. Although there was cultivar variation within each genus, patterns of postharvest responses have emerged. The largest category, with 53 cultivars, was one in which a holding preservative increased vase life of the following genera and species: acidanthera (Gladiolus murielae), basil (Ocimum basilicum), bee balm (Monarda hybrid), blackeyed susan (Rudbeckia hybrids), campanula (Campanula species), celosia (Celosia argentea), common ninebark (Physocarpus opulifolius), coneflower (Echinacea purpurea), coral bells (Heuchera hybrids), feverfew (Tanacetum parthenium), foxglove (Digitalis purpurea), ladybells (Adenophora hybrid), lisianthus (Eustoma grandiflorum), lobelia (Lobelia hybrids), obedient plant (Physostegia virginiana), ornamental pepper (Capsicum annuum), pincushion flower (Scabiosa atropurpurea), pinkflower (Indigofera amblyantha), seven-sons flower (Heptacodium miconioides), shasta daisy (Leucanthemum superbum), sunflower (Helianthus annuus), snapdragon (Antirrbinum majus), sweet william (Dianthus hybrids), trachelium (Trachelium caeruleum), and zinnia (Zinnia elegans). Hydrating preservatives increased the vase life of four basils, coral bells, and sunflower cultivars. The combined use of hydrator and holding preservatives increased the vase life of three black-eyed susan, seven-sons flower, and sunflower cultivars. Holding preservatives reduced the vase life of 14 cultivars of the following genera and species: ageratum (Ageratum boustonianum), false queen anne's lace (Ammi species), knotweed (Persicaria hybrid), lisianthus, pineapple lily (Eucomis comosa), sneezeweed (Helenium autumnale), yarrow (Achillea millifolium), and zinnia. Hydrating preservatives reduced the vase life of 18 cultivars of the following genera and species: feverfew, lisianthus, ornamental pepper, pineapple lily, seven-sons flower, shasta daisy, sneezeweed, sweet william, sunflower, trachelium, yarrow, and zinnia. The combined use of hydrating and holding preservatives reduced the vase life of 12 cultivars in the following genera and species: false queen anne's lace, feverfew, pincushion flower, sneezeweed, sunflower, trachelium, yarrow, and zinnia. Data for the remaining $\mathbf{5 0}$ cultivars were not significant among the treatments; these genera and species included beautyberry (Callicarpa americana), black-eyed susan, blue mist (Caryopteris clandonensis), calendula (Calendula officinalis), campanula, cleome (Cleome hasserliana), common ninebark, dahlia (Dablia hybrids), delphinium (Delphinium hybrids), flowering peach (Prunus persica forma versicolor), heliopsis (Heliopsis helianthoides), hemp agrimony (Eupatorium cannabinum), himalayan honeysuckle (Leycesteria formosa), hydrangea (Hydrangea paniculata), larkspur (Consolida hybrids), lily of the nile (Agapanthus hybrid), lisianthus, lobelia, ornamental pepper, pineapple lily, scented geranium (Pelargonium hybrid), sunflower, sweet william, and zinnia.

$\mathrm{E}$ ach year a wide variety of new cultivars and species are evaluated in the National Cut Flower Trial Programs administered by North Carolina State University and the Association of Specialty Cut Flower Growers. These new cultivars are tested at about 50 locations in the United States and Canada, providing valuable production and marketing information (Dole and Laushman, 2010; Dole et al., 2010). However, postharvest life, a key component of a successful cut flower cultivar, is not included in the trial program.
Commercially, cut stems are typically subjected to a hydrating solution and a holding solution. The purpose of a hydrator is to encourage water uptake. A commercial hydrator contains compounds to lower the $\mathrm{pH}$, as water with a low $\mathrm{pH}$ is more easily taken up by stems when compared with water of high pH (Gast, 2000; Regan and Dole, 2010). Hydrators do not include sugar and are not designed to be used for extended periods of time longer than $24 \mathrm{~h}$ (Armitage and Laushman, 2003; Halevy and Mayak, 1981). However, a holding preservative is intended to be used for extended periods of time, $24 \mathrm{~h}$ or longer, typically during transport and storage. They regularly contain a carbohydrate source, an antimicrobial agent, and an acidifying agent (Dole and Wilkins, 2005; Halevy and Mayak, 1981). The carbohydrates support the cut stem, the antimicrobial agent deters the growth of stemplugging microbes, and the acidifying agent helps slow microbial growth and encourages water uptake. Holding preservatives with a high percentage of carbohydrates aid in the opening of buds and in the development of flowers (Armitage and Laushman, 2003; Halevy and Mayak, 1981). In some cases, unamended water may be used in place of hydrator or holding solutions. The objective of this multiyear study was to identify patterns of postharvest responses to commercial hydrator and holding floral preservatives among 121 cultivars from 47 genera.

\section{Materials and methods}

Field-grown flowers were harvested between 7:00 AM and 10:00 $\mathrm{AM}$ at the optimum stage of development (Table 1). The lower half of the stem was stripped of its leaves and then placed into buckets filled with tap water within 5 min of being cut. Stems were then sorted into four similar groups based on stem length and diameter, flower bud number, flower size, as appropriate for the cultivar, and trimmed to a consistent length for each

\begin{tabular}{lllc}
\hline $\begin{array}{l}\text { Units } \\
\begin{array}{l}\text { To convert U.S. to SI, } \\
\text { multiply by }\end{array}\end{array}$ & U.S. unit & SI unit & $\begin{array}{l}\text { To convert SI to U.S., } \\
\text { multiply by }\end{array}$ \\
\hline 10 & $\%$ & $\mathrm{~mL} \cdot \mathrm{L}^{-1}$ & 0.1 \\
2.54 & inch(es) & $\mathrm{cm}$ & 0.3937 \\
1 & $\mathrm{mmho} / \mathrm{cm}$ & $\mathrm{dS} \cdot \mathrm{m}^{-1}$ & 1 \\
0.001 & $\mathrm{ppm}$ & $\mathrm{mL} \cdot \mathrm{L}^{-1}$ & 1000 \\
0.9464 & $\mathrm{qt}$ & $\mathrm{L}$ & 1.0567 \\
$\left({ }^{\circ} \mathrm{F}-32\right) \div 1.8$ & ${ }^{\circ} \mathrm{F}$ & ${ }^{\circ} \mathrm{C}$ & $\left(1.8 \times{ }^{\circ} \mathrm{C}\right)+32$
\end{tabular}


species, 30-45 cm. Two groups of stems were placed in hydrating solution or DI water for $4 \mathrm{~h}$, after which one group from each solution was placed in a holding solution and the other in DI water. Experiments conducted from 2002 to 2005 used Chrysal Professional RVB Hydrating Solution (Pokon \& Chrysal, Miami, FL) (hydrator) at $2 \mathrm{~mL} \cdot \mathrm{L}^{-1}$ for $4 \mathrm{~h}$ and Chrysal Professional no. 2 Processing Solution (holding) at $10 \mathrm{~mL} \cdot \mathrm{L}^{-1}$ until termination. Stems were placed in the hydration solution within $\mathrm{l} h$ after harvest. Experiments conducted from 2006 to 2009 used Floralife Hydraflor 100 (Floralife, Walterboro, SC) at $8 \mathrm{~mL} \cdot \mathrm{L}^{-1}$ (hydrator) for $4 \mathrm{~h}$ and Floralife Professional at $10 \mathrm{~mL} \cdot \mathrm{L}^{-1}$ (holding) for $44 \mathrm{~h}$, then the stems were placed in DI water until termination. Each cultivar was tested only for 1 year; therefore, it was exposed to only one brand of hydrator and holding combination. Initial $\mathrm{pH}$ and electrical conductivity (EC) of the solutions were recorded (Table 2) when the first cultivars were tested each year and every month thereafter using a combination pH/EC meter (HI 9813 GroCheck meter; Hanna Instruments, Woonsocket, RI). During all years, each stem was placed in a quart-size Mason jar in a completely randomized design, by cultivar, in a postharvest environment held at $20 \pm 2^{\circ} \mathrm{C}$ under $20-40$ $\mu \mathrm{mol} \cdot \mathrm{m}^{-2} \cdot \mathrm{s}^{-1}$ light for $12 \mathrm{~h} \cdot \mathrm{d}^{-1}$. For most species, 15 stems per treatment were tested, but occasionally 5-14 stems per treatment were used if sufficient stems were not available. Stems were terminated when "the average consumer" would discard them based on petal wilt, necrosis, discoloration or abscission, bent neck, leaf and stem discoloration, drying or general stem decline, depending on the species ( $\mathrm{Ta}$ ble 1). Vase-life data were collected and analyzed using analysis of variance (SAS 9.1; SAS Institute, Cary, NC). For genera with more than one cultivar,

\footnotetext{
Department of Horticultural Science, North Carolina State University, Raleigh, NC 27614

We gratefully acknowledge support from the American Floral Endowment, Association of Specialty Cut Flower Growers Research Foundation, and numerous suppliers. The authors thank Diane Mays, Beth Harden, Aliya Donnell, Leslie Tichner, Emma Locke, and Tina Krug for assisting with the postharvest studies.

${ }^{1}$ Graduate Research Assistant

${ }^{2}$ Professor

${ }^{3}$ Research Technician

${ }^{4}$ Corresponding author. E-mail: John_Dole@ncsu.edu.
}

data were combined if no significant differences occurred among cultivars. If differences among cultivars occurred, data were analyzed and presented separately for each cultivar. A separate analysis of sunflower and zinnia were conducted to determine the effect of changing brands of hydrator and holding preservatives.

\section{Results and discussion}

Many cultivars were unaffected by either hydrator or holding preservatives (Table 3 ). It is recommended that further testing be conducted, especially with the cultivars that included less than 10 replications. The variability in small number of stems can mask statistical significance that may be present, thus providing less than accurate results. For many species and cultivars discussed in this article, this is the first published report on vase life.

It is important to note that when the current results presented here conflict with previously published recommendations, each grower should assess his or her operation to determine the most practical use of hydrator and holding solutions for their unique situation. These differences could exist for several reasons, including differences in the specific cultivars tested, handling procedures (including timing, equipment, and weather), and postharvest environment. For the following genera, the vase life of one or more cultivars was significantly influenced by the treatments.

Acidanthera. Holding preservatives slightly increased vase life to 10.3 from $9.3 \mathrm{~d}$ for stems in water. Armitage and Laushman (2003) and Scoggins (2002) support using holding solutions in their recommendations. Armitage and Laushman (2003) noted that the vase life should be 5-7 d with a preservative.

Ageratum 'High tide white'. The longest vase lives were obtained with water or a hydrator for the first $4 \mathrm{~h}$, followed by holding in water. Stems placed in water alone, however, began to form roots, which greatly extended the vase life. In the commercial setting, a holding preservative is typically used, so that rooting would likely not occur. In the industry, it is recommended that a holding solution be used (Armitage and Laushman, 2003; Chain of Life Network, 2010; Scoggins, 2002). Even when held in the holding solution, ageratum still had a long vase life, ranging from 20.3 to $20.8 \mathrm{~d}$. In contrast, Armitage and Laushman (2003) indicated that the vase life would be from 7 to $10 \mathrm{~d}$ with preservative.

BASIL 'CARDINAL'. The longest vase life was obtained when hydrator and holding solutions were used together. Individually, both hydrator and holding solutions increased vase life.

BEE BALM 'RASPBERRY WINE'. The longest vase life was obtained when a holding solution was used after hydration with water. The Chain of Life Network (2010) recommended using a floral preservative, but warned that leaf discoloration or damage sometimes occurs.

Campanula. Although 'Heavenly Blue' (Campanula rapunculus), 'Champion Lavender Improved', and 'Champion White Improved' (C. medium) were unaffected by the treatments, the longest vase lives for 'Kent Belle' (C. takesimana) were obtained when a holding preservative was used after being hydrated with water or hydrator. It is recommended that a holding solution is used with this genus. Armitage and Laushman (2003), Bosma and Dole (2002), the Chain of Life Network (2010), and Scoggins (2002) also recommended using a floral preservative for campanula.

Celosia 'TOREador ReD'. The longest vase lives were obtained when a holding solution was used after being treated with either hydrator or water. Without the holding preservative, vase life dropped by half to 17.5 or $13.5 \mathrm{~d}$ with hydrator or water, respectively. However, with a holding preservative, stems discolored slightly and desiccated rapidly, but did not exhibit bent neck or yellow foliage, prompting the longer vase life. To maintain color and texture most similar to freshly harvested flowers, it is recommended that only water or only a hydrator is used. Armitage and Laushman (2003), the Chain of Life Network (2010), and Scoggins (2002) support this recommendation. Holcomb et al. (1998) noted that vase life was $16 \mathrm{~d}$ in tap water; commercial holding preservatives produced variable results and could reduce vase life if the incorrect concentration is used.

Common ninebark. 'Diabolo' was unaffected by treatment, whereas the vase life of 'Summer Wine' was increased by a holding solution. 
Table 1. The stage at which cut stems of each of the cultivars were harvested and criteria by which the vase life of each cultivars was ended.

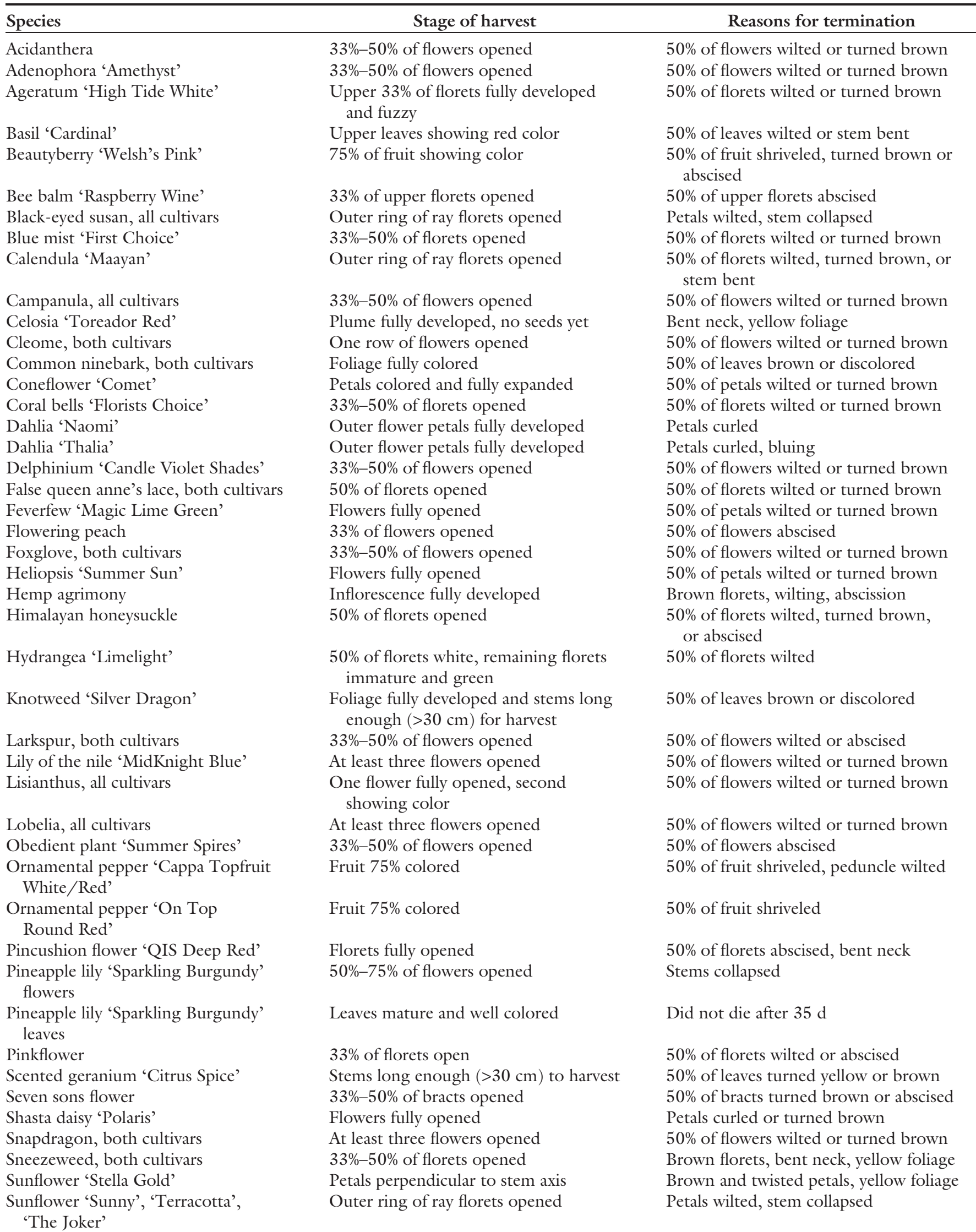


Table 1. (Continued) The stage at which cut stems of each of the cultivars were harvested and criteria by which the vase life of each cultivars was ended.

\begin{tabular}{|c|c|c|}
\hline Species & Stage of harvest & Reasons for termination \\
\hline $\begin{array}{l}\text { Sunflower (Helianthus salicifolia) } \\
\text { 'First Light' }\end{array}$ & First outer ring of ray florets opened & Petal wilt, stem collapse \\
\hline Sweet william, all cultivars & At least three flowers opened & $50 \%$ of flowers wilted or turned brown \\
\hline Trachelium, all cultivars & $50 \%-75 \%$ of florets opened & $50 \%$ of florets wilted or turned brown \\
\hline Yarrow 'Cassis' & Florets fully developed & $\begin{array}{l}50 \% \text { of florets turned brown, bent neck, } \\
\text { yellow foliage, wilting }\end{array}$ \\
\hline Zinnia, all other cultivars & $\begin{array}{l}\text { Outer petals fully expanded, one } \\
\text { row of florets opened }\end{array}$ & $50 \%$ of petals wilted or turned brown \\
\hline
\end{tabular}

Table 2. $\mathrm{pH}$ and electrical conductivity (EC) of hydrator and holding solutions over 8 years of study.

\begin{tabular}{|c|c|c|c|c|c|c|}
\hline \multirow[b]{2}{*}{$\underline{Y r}$} & \multicolumn{2}{|c|}{ Deionized water } & \multicolumn{2}{|c|}{ Hydrator $^{\mathrm{z}}$} & \multicolumn{2}{|c|}{ Holding $^{\mathrm{z}}$} \\
\hline & pH range & EC range $\left(\mathrm{dS} \cdot \mathrm{m}^{-1}\right)^{\mathrm{y}}$ & $\mathrm{pH}$ range & EC range $\left(\mathrm{dS} \cdot \mathrm{m}^{-1}\right)$ & pH range & EC range $\left(\mathrm{dS} \cdot \mathrm{m}^{-1}\right)$ \\
\hline 2002 & $4.5-4.6$ & 0.00 & $3.2-3.5$ & $0.46-0.54$ & $2.5-2.9$ & $0.44-0.53$ \\
\hline 2004 & $3.1-4.2$ & 0.00 & $-^{x}$ & - & $2.3-2.8$ & $0.41-0.44$ \\
\hline 2005 & $3.6-7.0$ & 0.00 & $3.1-3.6$ & $0.33-0.61$ & $2.1-2.8$ & $0.25-0.46$ \\
\hline 2006 & 3.7 & 0.00 & 2.3 & 0.61 & 2.8 & 0.37 \\
\hline 2009 & $3.6-4.6$ & 0.00 & $2.5-2.8$ & $0.79-0.93$ & $3.1-3.5$ & $0.38-0.45$ \\
\hline
\end{tabular}

${ }^{\text {zFrom }} 2002$ to 2005, Chrysal Professional RVB Hydrating Solution (hydrator; Pokon \& Chrysal, Miami, FL) and Chrysal Professional no. 2 Processing Solution (holding; Pokon \& Chrysal) were used; from 2006 to 2009, Floralife Hydraflor 100 (hydrator; Floralife, Walterboro, SC) and Floralife Professional (holding; Floralife) were used.

${ }^{\mathrm{y}} \mathrm{l} \mathrm{dS} \cdot \mathrm{m}^{-1}=1 \mathrm{mmho} / \mathrm{cm}$

${ }^{x}$ Data not collected

Coneflower 'COMET'. Holding preservatives increased vase life, and the longest vase life was obtained when a holding solution was used after hydration with water. Armitage and Laushman (2003) and Scoggins (2002) support the findings in these studies, whereas the Chain of Life Network (2010) warns against the use of holding solutions and recommends the use of only a hydrator. Armitage and Laushman (2003) indicated that vase life would be from 7 to $10 \mathrm{~d}$ with a preservative.

Coral bells 'FlORISTS CHOICE'. The longest vase life was obtained when hydrator and holding solutions were used together. Individually, both hydrator and holding solutions also increased vase life. Han (1998) also determined that using $0.5 \%$ sucrose as a pulse increased vase life of two Heuchera cultivars.

False QueEN ANne's lace. 'Casablanca' (Ammi visnaga) and 'Graceland' (A. majus) differed in optimal postharvest procedures. Vase life of 'Graceland' was reduced with the use of either a holding preservative alone or a hydrator and holding solution together. Except for the use of hydrator and holding solutions together, which reduced the vase life of 'Casablanca' slightly, all treatments had statistically similar vase lives. Floral preservatives would not be recommended for false queen anne's lace. In contrast, Armitage and Laushman (2003), Scoggins (2002), and the Chain of Life Network (2010) recommended using floral preservatives. Armitage and Laushman (2003) noted that the vase life would be from 5 to $8 \mathrm{~d}$ in preservative.

FeverfeW 'MAGIC Lime GReEN'. The longest vase life was obtained by using a holding solution after hydration with water. The use of a hydrator decreased vase life and produced an even shorter vase life when used in conjunction with a holding preservative.

Foxglove. For both cultivars, holding preservative slightly increased vase life when compared with water only and no significant differences occurred between cultivars. Therefore, a holding solution should be used. The Chain of Life Network (2010) recommended using a floral preservative to get a vase life of 10-14 d.

LADYBELLS 'AMETHYST'. Holding preservatives increased vase life, and the longest vase life was obtained with only a holding preservative.

Lisianthus. Cultivar interacted with treatment $(P \leq 0.0001)$ such that 11 of the 16 cultivars tested were unaffected by holding treatment; holding preservatives increased the vase life of three and decreased the vase life of two. Of the three cultivars that responded well to a holding preservative, vase life increased to an additional 1.5-6.5 d. Vase life decreased from 0.5 to $2.3 \mathrm{~d}$ for the two cultivars that were negatively affected by the holding solution. When data from individual cultivars were analyzed, hydrator preservative decreased the vase life of 'Twinkle Blue Blush'. Because of the variable response, individual cultivars should be tested. Regardless of the use of holding solution, a hydrator should not be used with 
Preliminary and Regional Reports

Table 3. Cultivars on which neither commercial hydrator nor holding solutions ${ }^{\mathrm{z}}$ had an effect.

\begin{tabular}{|c|c|c|c|c|}
\hline Genus & Cultivar & $\begin{array}{l}\text { Minimum } \\
\text { vase life }(d)^{y}\end{array}$ & $\begin{array}{c}\text { Avg vase } \\
\text { life } \pm \operatorname{SD}(d)^{x}\end{array}$ & $\begin{array}{c}\text { Stems } \\
\text { (no./treatment) }\end{array}$ \\
\hline Beautyberry & Welsh's Pink & 19 & $21.7 \pm 2.6$ & 15 \\
\hline Black-eyed susan & Prairie Sun & 12 & $22.8 \pm 6.7$ & 11 \\
\hline Blue mist & First Choice & 5 & $14.4 \pm 3.4$ & 15 \\
\hline Calendula & Maayan & 3 & $4.8 \pm 1.2$ & 15 \\
\hline Campanula & Champion Lavender Improved & 2 & $10.2 \pm 4.6$ & 15 \\
\hline Cleome & Sparkler Lavender & 1 & $5.9 \pm 1.3$ & 15 \\
\hline Common ninebark & Diabolo & 12 & $19.6 \pm 3.5$ & 11 \\
\hline \multirow[t]{2}{*}{ Dahlia } & Naomi & 4 & $5.7 \pm 1.1$ & 15 \\
\hline & Thalia & 3 & $6.4 \pm 1.1$ & 10 \\
\hline \multirow[t]{2}{*}{ Delphinium } & Candle Violet Shades & 4 & $9.0 \pm 2.7$ & 5 \\
\hline & Stiletto Indigo Blue & 6 & $9.7 \pm 2.0$ & 15 \\
\hline Himalayan honeysuckle & None & 9 & $12.3 \pm 2.7$ & 6 \\
\hline Hydrangea & Limelight $^{\mathrm{w}}$ & 6 & $11.3 \pm 3.4$ & 15 \\
\hline \multirow[t]{2}{*}{ Larkspur } & Cannes Chrystal Pink & 4 & $8.7 \pm 2.4$ & 7 \\
\hline & Cannes Purple Picotee & 4 & $8.1 \pm 2.2$ & 7 \\
\hline Lily of the nile & MidKnight Blue & 7 & $10.7 \pm 1.8$ & 8 \\
\hline \multirow[t]{7}{*}{ Lisianthus } & ABC 02153 White & 7 & $15.0 \pm 3.6$ & 6 \\
\hline & ABC 1-3 White & 5 & $9.8 \pm 1.7$ & 15 \\
\hline & ABC Lavender & 2 & $9.8 \pm 3.1$ & 13 \\
\hline & Advantage Cherry Sorbet & 8 & $13.4 \pm 2.6$ & 5 \\
\hline & Arena White & 11 & $15.7 \pm 1.4$ & 15 \\
\hline & Cadence Yellow & 10 & $14.1 \pm 2.1$ & 11 \\
\hline & Fioretti Green & 5 & $16.2 \pm 5.4$ & 13 \\
\hline Scented geranium & Citrus Spice & 8 & $20.9 \pm 8.1$ & 15 \\
\hline \multirow[t]{9}{*}{ Sunflower } & 565 & 8 & $10.9 \pm 1.4$ & 15 \\
\hline & Carmel & 9 & $14.5 \pm 1.5$ & 15 \\
\hline & Lemon Éclair & 7 & $8.1 \pm 1.1$ & 10 \\
\hline & Orange Queen & 1 & $9.5 \pm 4.5$ & 14 \\
\hline & Pro Cut Bicolor & 7 & $12.0 \pm 1.4$ & 10 \\
\hline & Pro Cut Orange & 4 & $14.6 \pm 3.2$ & 10 \\
\hline & Sun4U Bicolor & 7 & $10.6 \pm 1.5$ & 15 \\
\hline & Sun4U Orange & 8 & $11.5 \pm 1.4$ & 15 \\
\hline & Tapuz & 6 & $10.6 \pm 1.9$ & 15 \\
\hline \multirow[t]{3}{*}{ Sweet william } & Bouquet Rose & 9 & $11.4 \pm 1.4$ & 15 \\
\hline & Fandango Crimson & 3 & $9.4 \pm 2.4$ & 15 \\
\hline & Fandango Purple Picotee & 8 & $11.8 \pm 2.1$ & 15 \\
\hline \multirow[t]{2}{*}{ Zinnia } & Oklahoma Carmine & 8 & $18.5 \pm 4.5$ & 15 \\
\hline & Oklahoma Yellow & 8 & $22.5 \pm 6.4$ & 15 \\
\hline
\end{tabular}

${ }^{z}$ From 2002 to 2005, Chrysal Professional RVB Hydrating Solution (hydrator) and Chrysal Professional no. 2 Processing Solution (holding) were used, and from 2006 to 2009, Floralife Hydraflor 100 (hydrator) and Floralife Professional (holding) were used.

'Shortest lived replication.

${ }^{\mathrm{x}}$ Average overall four treatments $\pm \mathrm{SD}$.

"Hydrangea 'Limelight' can be harvested at three different times: when florets are still green, all florets are bright white with maturity, or florets have turned pinkish-green later in their development. The first stage was tested in this study and typically results in the shortest vase life (B. Wollam, personal communication).

"Leaves did not die even after $35 \mathrm{~d}$ in postharvest area.

lisianthus. Armitage and Laushman (2003), the Chain of Life Network (2010), Scoggins (2002), and Besemer
(1985) all recommended the use of a holding preservative with lisianthus. Armitage and Laushman (2003) noted that the vase life would be from 10 to $15 \mathrm{~d}$ and could be increased with the use of a preservative. 
Knotweed 'SILver dragon'. The longest vase life was obtained when stems were placed in plain water after hydration in water. The use of a holding preservative shortened the vase life. Some 'Silver Dragon' stems developed roots, which contributed to the remarkably long vase life. Even the shortest lived stem had an outstanding vase life, $19 \mathrm{~d}$.

Lobelia. 'Fan Blue' was unaffected by treatment, while the vase life of 'Compliment Mix' was slightly increased by a holding solution.

OBEDIENT PLANT 'SUMMER SPIRES'. Holding preservative increased the vase life to $5 \mathrm{~d}$ for stems held in water. Armitage and Laushman (2003), Scoggins (2002), and the Chain of Life Network (2010) strongly recommended the use of a holding preservative for obedient plant. As with our results, Armitage and Laushman (2003) noted that a vase life of $14 \mathrm{~d}$ could be obtained with the use of a holding solution.

Ornamental PePper. For all the three cultivars tested, the use of a commercial hydrator either reduced the vase life or had no effect, and so it should not be used. Cultivar interacted with treatment $(P=0.0202)$ such that the longest vase life for 'Cappa Topfruit White/Red' was obtained when a holding preservative was used without a hydrator, but the longest vase life for 'On Top Round Red' was obtained when hydrated with water, followed by either a holding preservative or water. Treatment had no effect on the vase life of 'Hot Purple'. Foliage wilted readily, while the fruit was still presentable; consequently, as much of the foliage should be removed at harvest as practical.

Pincushion FlOWER 'QIS DEEP RED'. The longest vase life was obtained using a holding preservative after hydration with water. Similarly, Armitage and Laushman (2003) indicated that the vase life would be 5-7 $\mathrm{d}$ in water and would increase to 7-10 $\mathrm{d}$ with a preservative. When a hydrator and holding solution were used together, vase life was shortest. Industry standards (Armitage and Laushman, 2003; Chain of Life Network, 2010; Scoggins, 2002) support the use of a holding preservative.

Pineapple LiLy 'SPARKLING BURGUNDY'. Vase life for flowers was longest when stems were placed in plain water. Both hydrator and holding solutions reduced vase life, and if both solutions were used, vase life dropped to a still acceptable $10.6 \mathrm{~d}$. Although a holding preservative decreased the vase life, Eucomis could still be used in a bouquet and have a vase life competitive with other species in the vase. Eucomis 'Sparkling Burgundy' leaves were also exceptionally long lasting with an average and minimum vase life of $35 \mathrm{~d}$. The leaves held in water rooted, preventing a final determination of vase life.

Pinkflower. The longest vase life was obtained when a holding solution was used after hydration with water.

SEVEN SONS FLOWER. The longest vase life was obtained when both hydrator and holding solutions were used. The use of a holding preservative alone also extended the vase life when compared with plain water. The bracts of this species were very brittle and tended to be abscised readily (personal observation).

Shasta DAISY 'POLARIS'. The longest vase life was obtained when a holding solution was used after hydration with water. Overall, the use of a holding preservative increased vase life, but the use of a hydrator decreased vase life.

SnAPDragon. Both snapdragon cultivars responded well in a holding preservative; the longest vase lives were obtained when a holding preservative was used, regardless of hydrator use. Industry recommendations (Armitage and Laushman, 2003; Chain of Life Network, 2010; Scoggins, 2002) support the use of a holding preservative. Armitage and Laushman (2003) noted that snapdragon typically has a vase life of 5-8 $\mathrm{d}$ in water.

SNEEZEWEED. For both cultivars, the combined use of hydrators and holding solutions reduced vase life; plain water was as effective as either a hydrator or a holding solution alone. No significant differences occurred between cultivars $(P \leq 0.05)$. Therefore, sneezeweed should be placed in plain water after harvest and no commercial products used.

Sunflower. Cultivar interacted with treatment $(P \leq 0.0001)$ of the 26 cultivars tested; nine were unaffected by treatment, holding preservative increased the vase life of 16 , hydration solutions increased the vase life of two, and the use of both hydrator and holding preservatives increased vase life of one cultivar. However, hydrator solutions reduced the vase life of three cultivars and combining a hydrator with a holding solution decreased the vase life of two cultivars. It should be noted that some cultivars responded in more than one way to treatments (i.e., positively to a holding preservative but negatively to a hydrator). All cultivars either benefited or were unaffected by a holding preservative when used alone. An exception was that holding solutions for 'Sunny' stems caused slight petal tip browning (personal observation). 'Terracotta' petal color also deepened with age (personal observation), but that was not considered a positive or a negative change. Therefore, a holding preservative should be used with cut sunflowers. The Chain of Life Network (2010) supports the use of hydrators, holding preservatives, or plain water for postharvest solutions of sunflowers, but states that the most benefit is gained from holding preservatives. Armitage and Laushman (2003) suggested that a floral preservative be used, which would result in a 7-10 d vase life.

Sweet william. Cultivar interacted with treatment $(P \leq 0.0001)$ such that the vase life of six of the nine cultivars tested, Amazon Neon Duo, Bouquet Purple, Sweet Coral, Sweet Red, Sweet Scarlet, and White with Ring, increased with the use of a holding solution; the other three were unaffected by the treatments. Hydrator had no effect, except for reducing vase life of 'Sweet Red'. However, leaf browning of 'Sweet Coral' and 'Sweet Red' stems occurred when the holding solution was used in conjunction with a hydrator (personal observation). Thus, it is recommended that a holding preservative without a hydrator be used for sweet william. The Chain of Life Network (2010) supports this recommendation. Armitage and Laushman (2003) indicated that the vase life would be $7-10 \mathrm{~d}$, but did not specify the solution.

Trachelium. Vase life was the longest for all three cultivars when a holding solution was used without a hydrator. Cultivar interacted with treatment $(P=0.0406)$ such that a hydrator decreased the vase life of 'Summer Purple', regardless of holding solution, whereas the use of a hydrator shortened the vase life of 'Summer White' and 'Lake Louise Purple' when used in conjunction with a holding solution. Therefore, it is recommended that only a holding 


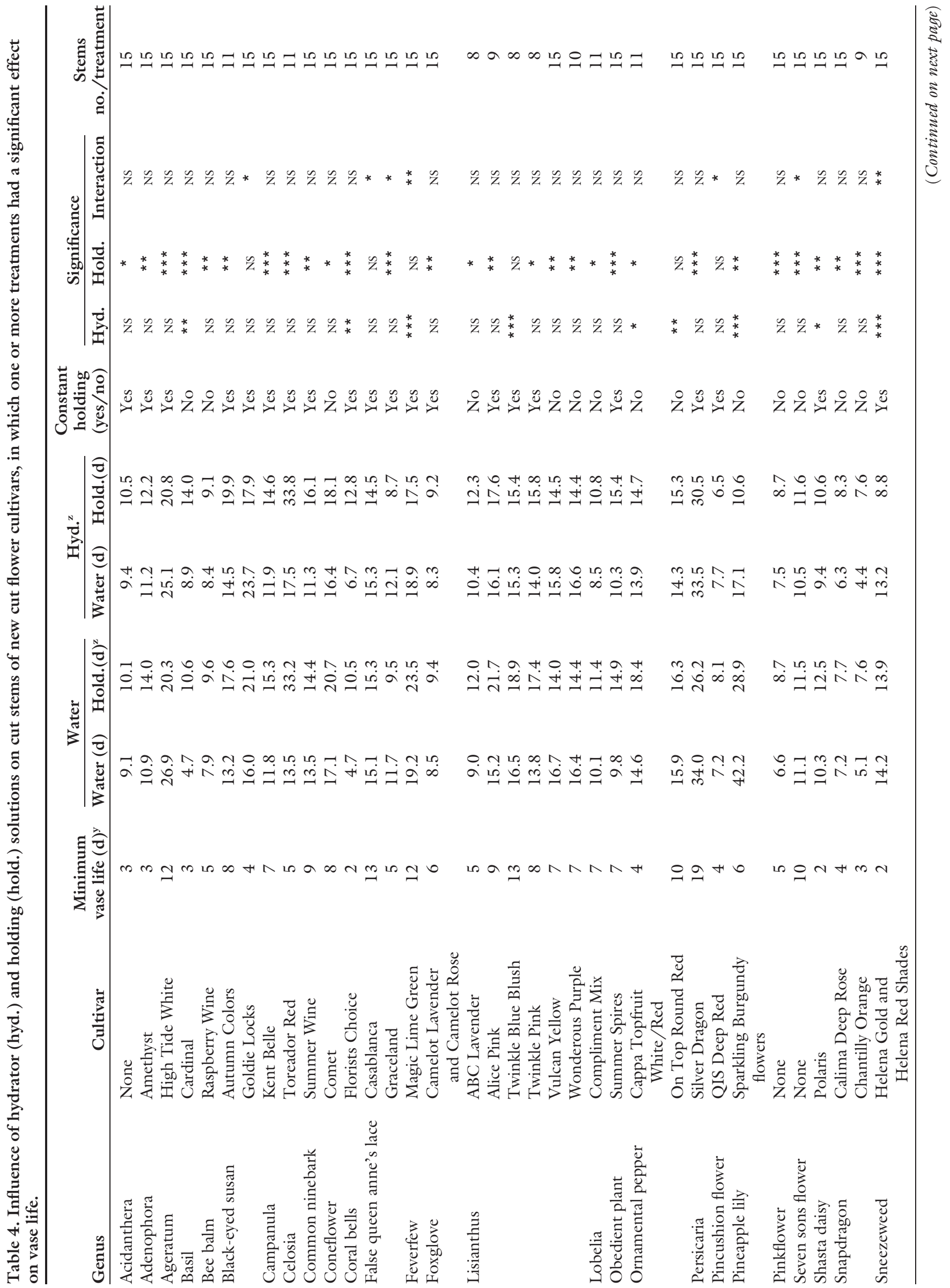




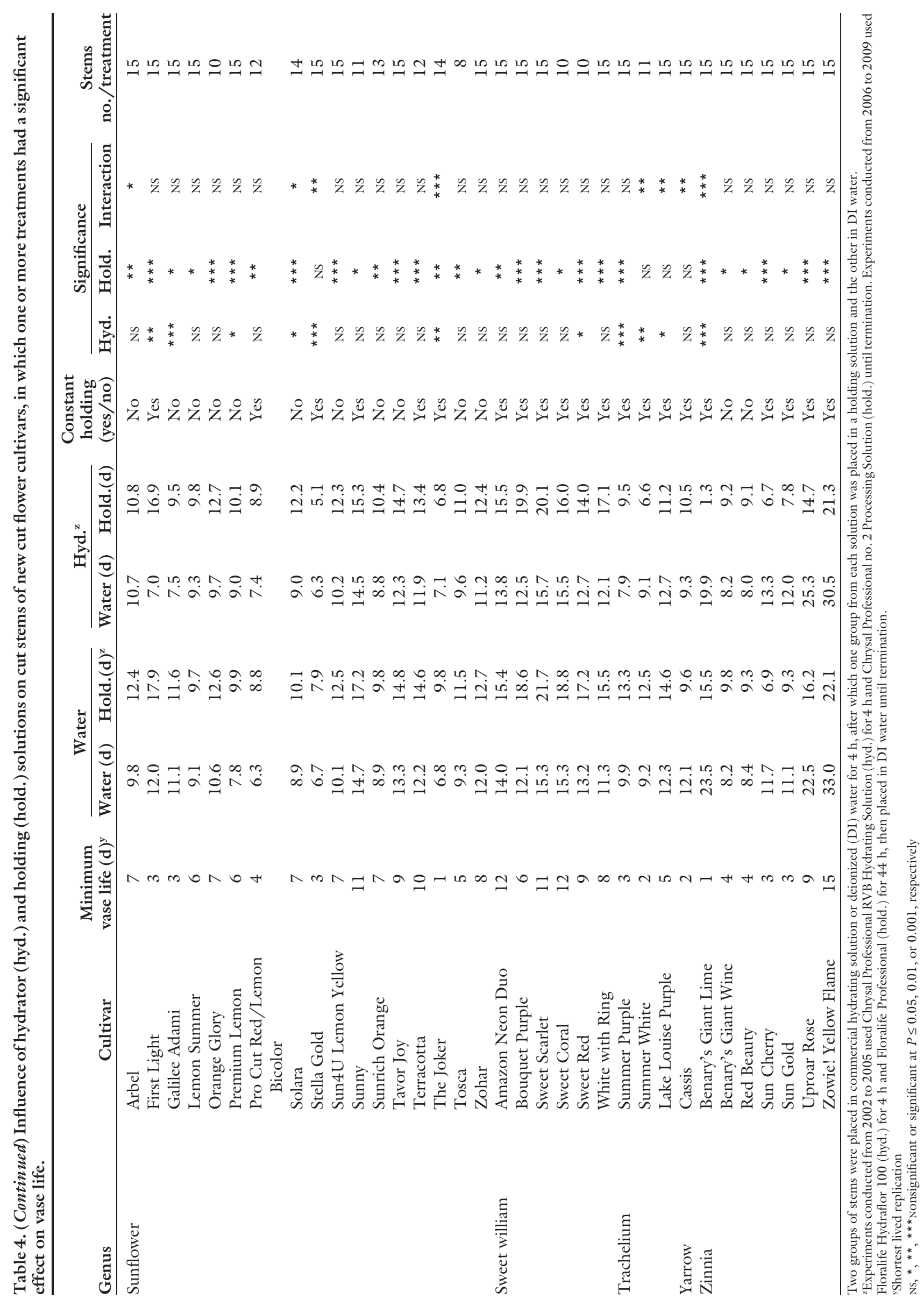

Hortlechnology • December 2010 20(6) 
solution be used for trachelium. The Chain of Life Network (2010) and Dole et al. (2009) support this recommendation.

Yarrow 'CASSIS'. The longest vase life was obtained by placing stems in plain water (Table 4). Armitage and Laushman (2003) indicated that either water or holding preservative could be used to obtain a 3-4 d vase life and the Chain of Life Network (2010) recommended the use of floral preservatives.

ZinNia. Cultivar interacted with treatment $(P \leq 0.0001)$ such that the vase life for five of the nine cultivars was shorter with the use of a holding preservative, vase life of two cultivars increased by using a holding preservative, and two cultivars were unaffected by the treatments. The longest vase lives for 'Sun Cherry', 'Sun Gold', 'Uproar Rose', and 'Zowie! Yellow Flame' were obtained when plain water was used after hydration with either a hydrator or water. For 'Benary's Giant Lime', the longest vase life was obtained when stems were placed in plain water after hydration with water. The use of a hydrator or a holding preservative decreased the vase life, but when used together, the vase life dropped by 3 weeks to $1.3 \mathrm{~d}$. Petal margins browned and began to curl within $\mathrm{l} d$ when the hydrator and holding preservative were used (personal observation). The vase life of 'Benary's Giant Wine' and 'Red Beauty' was longer with the use of a holding preservative. The Chain of Life Network (2010) states that zinnias are sensitive to the use of holding preservatives. The Chain of Life Network warns "...damage can result if the solution is made too strong (over $1 \%)$, too weak $(0.5 \%)$, and/or if the wrong flower food brand is used." Because of the unpredictability of a holding preservative on zinnias and the benefits of water, it is recommended that each cultivar be tested.

Switching from Chrysal products and procedures (2002-2005) to Floralife products (2006-2009) had no effect as response patterns were similar among Helianthus and Zinnia cultivars (data not presented). In addition, there was no difference between leaving the stems in holding solution for $2 \mathrm{~d}$ or until termination, which suggests that the effect of solution uptake was not significantly greater after $2 \mathrm{~d}$ than over the course of the stems' life. These results are not surprising as water uptake is highest immediately after harvest (Doi et al., 1999; Mayak et al., 1974) and at the commencement of rehydration.

Of the 121 taxa tested, 16 had a vase life longer than $21 \mathrm{~d}$ for at least one of the treatments, 38 had a vase life of 14-21 d and 39 had a vase life of 10-14 d, indicating that most of the taxa tested would be suitable for commercial production. However, these results represent optimal postharvest handling conditions without cold storage or shipping, which can reduce vase life. Commercial producers typically store cut flowers for many days and have to ship flowers either dry in boxes or wet in buckets of floral solution. Thus, the indicated vase life would likely be the maximum and commercial producers should expect shorter vase lives. This is supported by the fact that we generally reported a longer vase life for species that were also described in Armitage and Laushman (2003), which often relied on grower observations for determining vase life.

For the majority of taxa, either all treatments produced a similar vase life (Table 3 ) or treatment with a holding preservative produced the longest vase life (Table 5 ), indicating that holding preservatives can be used with most taxa. However, a universal

Table 5. Number of genera and cultivars whose response to floral preservatives fits the indicated categories.

\begin{tabular}{lcc}
\hline Category & Genera (no.) & Cultivars (no.) \\
\hline Holding-positive effect & 25 & 53 \\
Holding-negative effect & 8 & 14 \\
Hydrator-positive effect & 3 & 4 \\
Hydrator-negative effect & 12 & 18 \\
Both hydrator and holding-positive & 3 & 3 \\
Both hydrator and holding-negative & 8 & 12 \\
\hline
\end{tabular}

Cultivars that had no response to any treatment are listed in Table 3. Cultivars can fit more than one category. recommendation for use of a holding preservative cannot be made as it reduced the vase life of 14 cultivars in 8 genera. Interestingly, commercial hydrators had a less positive effect on vase life as they increased the vase life of only four cultivars in three genera and reduced the vase life of 18 cultivars in 12 genera. Thus, hydrator preservatives need not be used with most taxa. Of course, it is always best to conduct small scale, on-farm research as each operation has a unique situation, with variable processing procedures and commercial solutions used.

\section{Literature cited}

Armitage, A.M. and J.M. Laushman. 2003. Specialty cut flowers, 2 nd ed. Timber Press, Portland, OR.

Besemer, S. 1985. Lisianthus postharvest treatments. Flower growing and marketing, Univ. California Coop. Ext. Sept. 2.

Bosma, T. and J.M. Dole. 2002. Postharvest handling of cut Campanula medium flowers. HortScience 37:954958.

Chain of Life Network. 2010. Floral crop database. 12 Sept. 2010. <http://www. chainoflifenetwork.org/moa/dbs/floral_ crops/default.cfm>.

Doi, M., M. Miyangawa-Namao, K. Inamoto, and H. Imanishi. 1999. Rhythmic changes in water uptake, transpiration and water potential of cut roses as affected by photoperiods. J. Jpn. Soc. Hort. Sci. 68: 861-867.

Dole, J. and J. Laushman. 2010. 2009 ASCFG perennial trials. The Cut Flower Qrtly. 22(1):44-50.

Dole, J., I. McCall, and E. Regan. 2010. 2009 ASCFG cut flower seed trial. The Cut Flower Qrtly. 22(1):24-43.

Dole, J.M., Z. Viloria, F.L. Fanelli, and W. Fonteno. 2009. Postharvest evaluation of cut dahlia, linaria, lupine, poppy, rudbeckia, trachelium and zinnia. HortTechnology 19:593-600.

Dole, J.M. and H.F. Wilkins. 2005. Floriculture: Principles and species, 2nd ed. Prentice Hall, Upper Saddle River, NJ.

Gast, K.L.B. 2000. Water quality: Why it is so important for florists. Kansas State Univ. Ext. Publ. MF-2436.

Halevy, A.H. and S. Mayak. 1981. Senescence and postharvest physiology of cut flowers. Part 2. Hort. Rev. (Amer. Soc. Hort. Sci.) 3:59-143. 
Han, S.S. 1998. Postharvest handling of cut Heuchera sanguinea Engelm. flowers: Effects of sucrose and silver thiosulfate. HortScience 33:731-733.

Holcomb, E.J., W. Raffensberger, and R. Berghage. 1998. Postharvest treatments for Celosia. Pennsylvania Flower Growers Bul. 450:3.
Mayak, S., A.H. Halevy, S. Sagie, A. BarYosef, and B. Bravdo. 1974. The water balance of cut rose flowers. Physiol. Plant. 32:15-22.

Regan, E.M. and J.M. Dole. 2010. Determining optimum $\mathrm{pH}$ and EC levels for extended vase life of cut Rosa 'Freedom',
'Charlotte', and 'Classy'. Acta Hort. 870:263-271.

Scoggins, H.L. 2002. Field production of cut flowers: Potential crops. Virginia Tech. Ext. Publ. 426-619. 